\section{AMERICAN-EURASIAN JOURNAL OF SUSTAINABLE AGRICULTURE}

\title{
The Influence Of Entrepreneurial Orientation, Innovation And Marketing Strategies To Competitiveness Of Food Sector Msmes In Makassar
}

\author{
${ }^{1}$ Revy Alviany, ${ }^{1}$ Mahyuddin, ${ }^{1}$ Musran Munizu, ${ }^{1}$ Sitti Nurani Sirajuddin, ${ }^{2}$ Rezky Ariany Aras \\ ${ }^{1}$ Agribusiness Study Program, Graduate School Hasanuddin University, Makassar,90245, Indonesia \\ ${ }^{2}$ Psychology Study Program, Bachelor, Hasanuddin University, Makassar, 90245, Indonesia
}

Received date: 12 February 2019, Accepted date: 15 May 2019, Online date: 3 June 2019

\author{
Address for Correspondence: \\ Revy Alviany, Agribusiness Study Program, Graduate School Hasanuddin University, Makassar,90245, Indonesia \\ E-mail: revyalviany@pasca.unhas.ac.id
}

Copyright () 2019 by authors and American-Eurasian Network for Scientific Information.

This work is licensed under the Creative Commons Attribution International License (CC BY).

http://creativecommons.org/licenses/by/4.0/

\section{(c) (i) Open Access}

\begin{abstract}
This research aimed to analyze the influence of orientation, innovation and marketing strategies on competitiveness of food sector MSMEs in Makassar, South Sulawesi. This research was conducted in February - April 2019, with the number of respondents 80 entrepreneurs food sector. The data analysis used a quantitative approach is Structural Equation ModellingPartial Least Square (SEM-PLS) using SmartPLS 3.0. This research shows that entrepreneurial orientation, innovation, and marketing strategy has a positive and significant impact on MSME's competitiveness with 0.05 level of significance because the p-value for entrepreneurial orientation was lower than 0.05 , precisely 0.003 with a coefficient of 0.243 . In innovations, the pvalue was $0.001<0.05$, which means that innovation has a positive and significant effect on competitiveness with a coefficient value of 0.332 . The marketing strategy also has a positive and significant impact on competitiveness with 0.05 level of significance, with a p-value of 0.004 that was even lower than 0.05 , and a coefficient of 0.295 which means for every one percent increase in marketing strategy will improve competitiveness by 29.5 percent.
\end{abstract}

\section{KEYWORDS}

Micro small medium enterprises (MSME), entrepreneurial orientation, innovation, marketing strategy, competitiveness

\section{INTRODUCTION}

The existence of Micro, Small, and Medium Enterprises (MSME) cannot be eliminated nor ignored from our day to day activity. MSME has a significant and strategic role in the national economy[1]. It was proven by $60 \%$ of MSME's contribution to Indonesia's Gross Domestic Product (GDP). Through MSME, unemployment number caused by the unabsorbed workforce is reduced. MSME sector has also proven to be a resilient economic pillar in the face of critical times during the economic crisis. Its important role is also shown in the aspect of income equality, where MSME played an important role in holding back the rate of urbanization while supporting equality in rural economic developments[2].

However, MSME's contribution is not yet optimal in the market competition, both domestic and foreign. This is caused by various problems faced by MSME players, especially in Makassar. First, innovation 
Revy Alviany et al., 2019. The Influence of Entrepreneurial Orientation, Innovation and Marketing Strategies To Competitiveness Of Food Sector Msmes In Makassar /American-Eurasian Journal of Sustainable Agriculture. 13(2): 61-67. DOI: 10.22587/aejsa.2019.13.2.7

and industrial technology updates are still not optimal. This lack of business innovation is also due to the lack of business knowledge of the business actors that should have been obtained through training on proper business innovation and management. The second problem is the conventional and traditional mindset of business actors. The third problem is the lack of financial access for the MSME actors that could have been a major help in developing their business to a larger scale.

The fourth and last problem lies in the marketing aspect. Business actors are still constrained in terms of marketing. The markets for MSMEs are still scattered and have not been connected yet so that MSMEs are still relying on exhibitions held by the government offices. This weakness does not only inhibit the growth of MSME, but also weaken MSME's competitiveness. To be able to stand out in the market and have a competitive advantage, MSMEs need to implement a good marketing strategy and technology [3]. This is supported by Stanton's opinion in Rahmat (2016) [4], that the strategy is a series of grand designs that illustrate how a company should operate to achieve its objectives. Therefore, running a business requires development through marketing strategy because in crisis conditions small businesses are the ones that have proven their ability to survive and show growth in their income. Furthermore, the comparative advantage of a business lies on the entrepreneur ability in managing human resources, and utilizing both the variable and fixed costs efficiently, including selling products with lower price than their competitors [5]. Competitiveness related to the company's ability to innovate on it's product [6].

\section{MATERIALS AND METHODS}

The study was conducted in Makassar city, South Sulawesi, Indonesia. Primary and secondary data were collected for the study. The primary data was obtained from respondents through direct interviews and questionnaires comprising of the entrepreneur's characteristics; entrepreneurial orientation, innovations, marketing strategies and competitiveness variables. The secondary data was obtained through relevant research agencies. There are 355 MSMEs in the food sector in Makassar that is recorded in the Department of Trade and Industry, Department of Cooperative and MSME, and Integrated Business Service Center. The samples in this study were collected using nonprobability sampling technique with purposive sampling method taken in Makassar city. The purposive sampling method is used because the respondents are selected according to the purpose and criteria set by the researcher. There are 80 entrepreneurs participated as respondents for this study. The study used a quantitative approach with Structural Equation Modelling-Partial Least Square (SEM-PLS) using SmartPLS 3.0 application.

\section{RESULTS AND DISCUSSION}

\section{Characteristics of Respondents}

General characteristics of respondents were derived from field data collection that includes age, gender, formal education, number of employees, and how long have the business run. The average age of respondents was 2035 years $(50 \%)$; average gender of respondents were women $(70 \%)$; last formal education was bachelor; the average total of labor was $1-5$ person $(93.75 \%)$, and the average length of business were $1-5$ years $(91.25 \%)$.

\section{Entrepreneurial Orientation, Innovation and Marketing Strategies on Competitiveness (Structural Partial Least Square Modeling Analysis)}

The first stage in the PLS analysis is the evaluation of measurement models. The measurement model showed how the manifest variable represents the latent variable. Measurement model evaluation was carried out against the construction reflected by the indicators. Based on the PLS process, the resulting initial model can be seen in Figure 1. 
Revy Alviany et al., 2019. The Influence of Entrepreneurial Orientation, Innovation and Marketing Strategies To Competitiveness Of Food Sector Msmes In Makassar /American-Eurasian Journal of Sustainable Agriculture. 13(2): 61-67. DOI: 10.22587/aejsa.2019.13.2.7

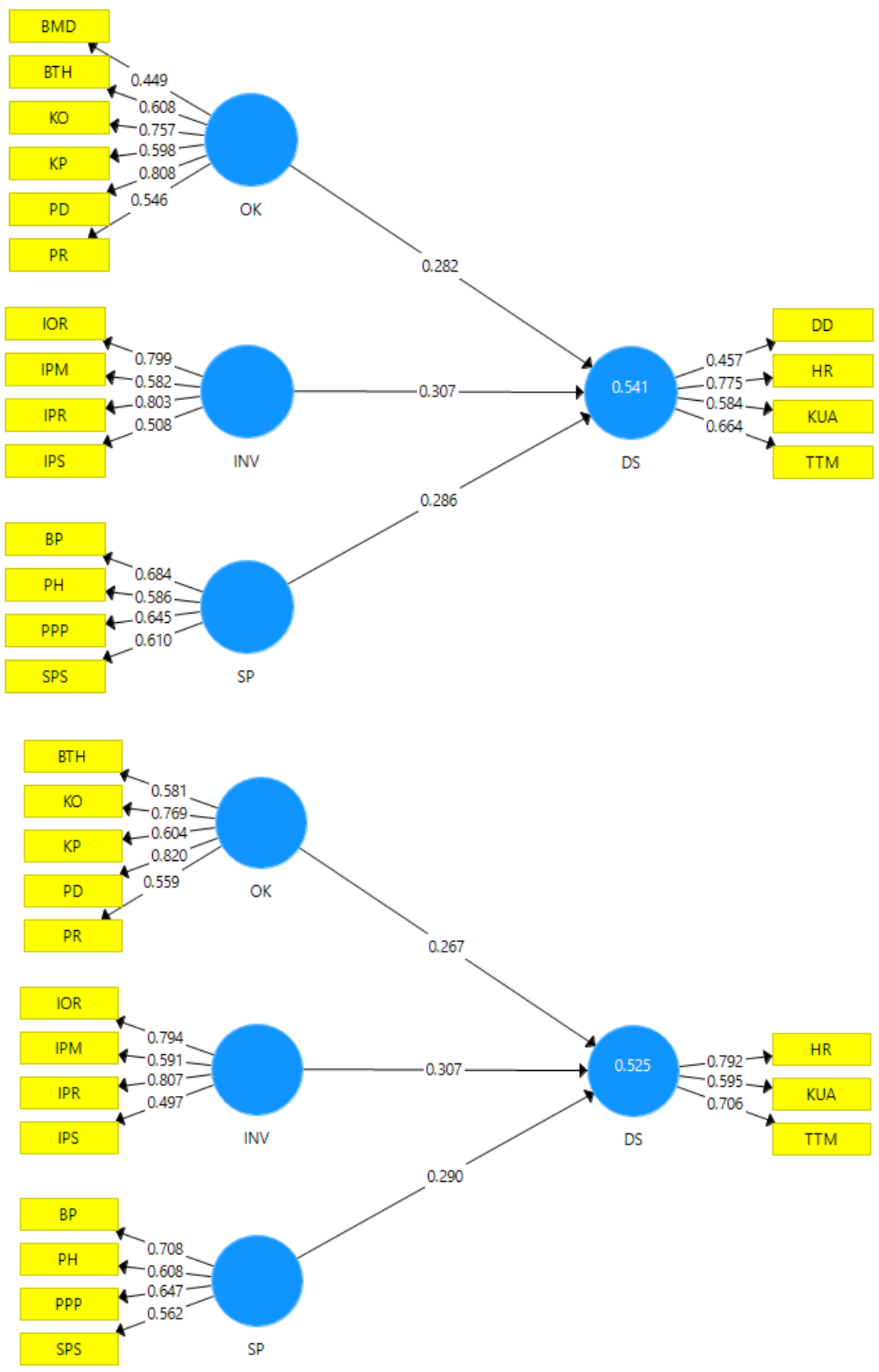

Figure 1. Initial Model Analysis

Figure 1 explains that the evaluation of the measurement model at the outer model assessment stage was done by comparing the loading factor with the default value of 0.5 . In addition, based on this model there were three indicators with loading factor $(\lambda)$ value that was below the 0.5 standards. Those indicators were BMD (future oriented) with a loading factor of 0.449, IPS (Innovation, Process, and Technology) with 0.497, and DD (Delivery Dependability) with 0.457 . This result showed that not all indicators in this study were valid to represent the latent variables. Therefore, it needed to be re-validated to get the best final model. The next step was to exclude the loading factor that is below 0.5 and then conduct the modified PLS algorithm process that had given a valid result. The manifest variables that reflected the latent variables were BTH (task and result oriented), KO (originality), KP (leadership), PD (confidence), PR (risk taker), IOR (organization innovation), IPM (marketing innovation), IPR (product innovation), BP (promotion program), PH (price-setting), PPP (market position setting), SPS (market segmentation), HR (price), KUA (quality), and TTM (time to market). The following were the final model images after re-estimation: 
Revy Alviany et al., 2019. The Influence of Entrepreneurial Orientation, Innovation and Marketing Strategies To Competitiveness Of Food Sector Msmes In Makassar /American-Eurasian Journal of Sustainable Agriculture. 13(2): 61-67. DOI: 10.22587/aejsa.2019.13.2.7

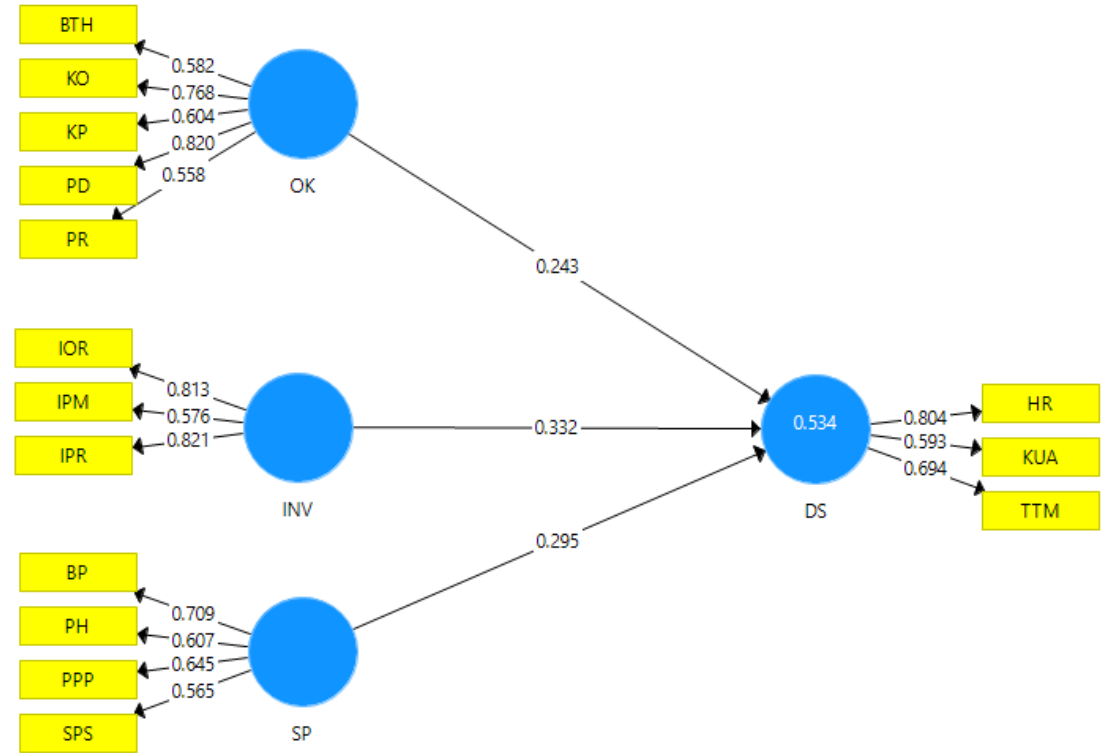

Figure 2. Model Analysis Results After Re-estimation

The study consisted of two latent variables namely exogenous and endogenous latent. The exogenous latent comprises entrepreneurial orientation and innovation and marketing strategy. Endogenous latent consisted of competitiveness. The manifest variables consisted of 15 indicators which were OK1, OK2, OK3, OK4, OK5, INV1, INV2, INV3, SP1, SP2, SP3, SP4, DS1, DS2 and DS3. All variables used a likert scale of 1 to 5.

Evaluation of the measurement model on the initial factor. The evaluation of the outer model was done by comparing the loading factor. The loading value factor is a reflective measure with a standard of 0.5 . Data analysis using PLS starts with model measurement (outer model) which is an evaluation against measurements of each latent variable or indicator measurement of each variable [7]. Convergent validity which is an individual reflective measurement is considered high if it correlates higher than 0.70 with the construction to be measured. Nevertheless, for preliminary research of scale measurement development, loading value of 0.30 to 0.60 is considered sufficient. The first stage in the PLS analysis is the measurement model evaluation. The measurement model shows how manifests variables or observed variables represent the latent variable to be measured. Table 1 shows the loading factor value after re-estimation.

Table 1. Loading Factor Value After Re-estimation

\begin{tabular}{|l|l|c|c|}
\hline \multicolumn{1}{|c|}{ Latent Variable } & \multicolumn{1}{|c|}{ Manifest Variable } & $\begin{array}{c}\text { Loading } \\
\text { Factor }\end{array}$ & Remarks \\
\hline \multirow{3}{*}{$\begin{array}{l}\text { Entrepreneurial Orientation } \\
\text { (OK) }\end{array}$} & Task and result oriented (OK1) & 0.582 & Valid \\
\cline { 2 - 4 } & Originality (OK2) & 0.768 & Valid \\
\cline { 2 - 4 } & Leadership (OK3) & 0.604 & Valid \\
\cline { 2 - 4 } & Confidence (OK4) & 0.820 & Valid \\
\cline { 2 - 4 } & Risk taker (OK5) & 0.558 & Valid \\
\hline Innovation (INV) & Organization innovation (INV1) & 0.813 & Valid \\
\cline { 2 - 4 } & Marketing innovation (INV2) & 0.576 & Valid \\
\cline { 2 - 4 } & Produk innovation (INV3) & 0.821 & Valid \\
\hline \multirow{5}{*}{ Marketing Strategy (SP) } & Promotion program (SP1) & 0.709 & Valid \\
\cline { 2 - 4 } & Price setting (SP2) & 0.607 & Valid \\
\cline { 2 - 4 } & Market positioning (SP3) & 0.645 & Valid \\
\cline { 2 - 4 } & Market segmentation (SP4) & 0.565 & Valid \\
\hline Competitiveness (DS) & Price (DS1) & 0.804 & Valid \\
\cline { 2 - 4 } & Quality (DS2) & 0.593 & Valid \\
\cline { 2 - 4 } & Time to market (DS3) & 0.694 & Valid \\
\hline
\end{tabular}

Next is looking at the value of Composite Reliability that shows the accuracy, consistency of a measurement tools in conducting a measurement. Composite realibility $(\mathrm{CR})>0.7$ where all CRs are reliable, is presented in Table 2 . 
Revy Alviany et al., 2019. The Influence of Entrepreneurial Orientation, Innovation and Marketing Strategies To Competitiveness Of Food Sector Msmes In Makassar /American-Eurasian Journal of Sustainable Agriculture. 13(2): 61-67. DOI: 10.22587/aejsa.2019.13.2.7

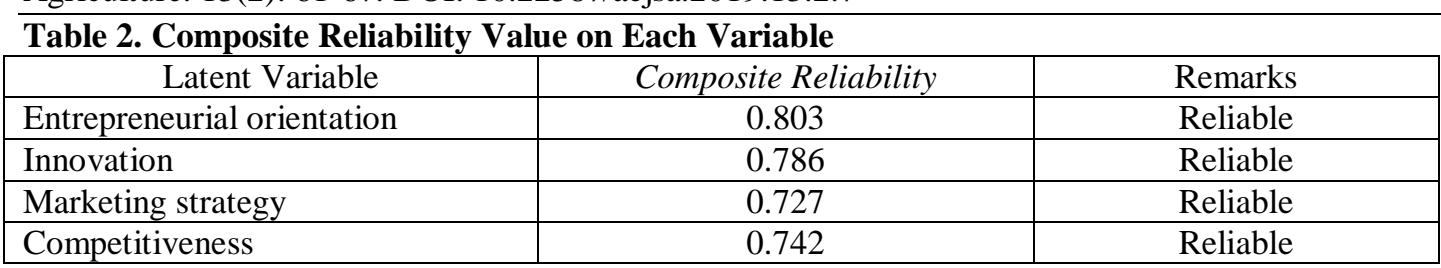

Next step is to see the discriminant validity of cross-loading criteria which is another criterion in measurement evaluation in which every indicator correlation of each latent variable to its own latent variable has a value larger than the correlation to the other latent variables as presented in Table 3.

Table 3. Validity Analysis of Discriminant Cross Loading Criteria

\begin{tabular}{|l|c|c|c|c|}
\hline \multicolumn{1}{|c|}{ Indicator } & Competitiveness & Innovation & $\begin{array}{c}\text { Entrepreneurial } \\
\text { Orientation }\end{array}$ & $\begin{array}{c}\text { Marketing } \\
\text { Strategy }\end{array}$ \\
\hline PD & 0.490 & 0.451 & $\mathbf{0 . 8 2 0}$ & 0.375 \\
\hline BTH & 0.271 & 0.347 & $\mathbf{0 . 5 8 2}$ & 0.330 \\
\hline PR & 0.229 & 0.249 & $\mathbf{0 . 5 5 8}$ & 0.253 \\
\hline KP & 0.284 & 0.480 & $\mathbf{0 . 6 0 4}$ & 0.412 \\
\hline KO & 0.561 & 0.511 & $\mathbf{0 . 7 6 8}$ & 0.310 \\
\hline IPR & 0.577 & $\mathbf{0 . 8 2 1}$ & 0.645 & 0.431 \\
\hline IPM & 0.291 & $\mathbf{0 . 5 7 6}$ & 0.278 & 0.371 \\
\hline IOR & 0.521 & $\mathbf{0 . 8 1 3}$ & 0.390 & 0.460 \\
\hline SPS & 0.376 & 0.329 & 0.336 & $\mathbf{0 . 5 6 5}$ \\
\hline PPP & 0.330 & 0.482 & 0.312 & $\mathbf{0 . 6 4 5}$ \\
\hline PH & 0.375 & 0.294 & 0.196 & $\mathbf{0 . 6 0 7}$ \\
\hline BP & 0.423 & 0.332 & 0.370 & $\mathbf{0 . 7 0 9}$ \\
\hline HR & $\mathbf{0 . 8 0 4}$ & 0.520 & 0.461 & 0.568 \\
\hline KUA & $\mathbf{0 . 5 9 3}$ & 0.289 & 0.328 & 0.262 \\
\hline TTM & $\mathbf{0 . 6 9 4}$ & 0.510 & 0.439 & 0.374 \\
\hline
\end{tabular}

Table 3 shows that the cross-loading indicator value that measures the latent variable had a higher value compared to other variables. Competitiveness variable had a higher cross-loading value than innovation, entrepreneurial orientation, and marketing strategy. This was similar to the other variables. The cross-loading value of each indicator for each variable already had the highest outer loading for the variables it had formed, thus every indicator for each variable in this study have had a good validity [8].

Other than cross-loading criteria, discriminant validity can also be measured based on Fornell-Larcker criteria. This criterion compares the correlation of a latent variable with another with its AVE roots. Table 4 indicates that the discriminant validity criteria of Fornell-Larcker in this study were fulfilled so that all the results of the above criteria assessment proved that the reflective outer model of the study is valid.

Table 4. Latent Variable Correlation, AVE and AVE Roots

\begin{tabular}{|l|c|c|c|c|c|c|}
\hline $\begin{array}{c}\text { Latent } \\
\text { Variable }\end{array}$ & DS & INV & OK & SP & AVE & AVE Roots \\
\hline DS & 1.000 & & & & 0.493 & 0.702 \\
\hline INV & 0.647 & 1.000 & & & 0.556 & 0.745 \\
\hline OK & 0.590 & 0.617 & 1.000 & & 0.456 & 0.675 \\
\hline SP & 0.598 & 0.560 & 0.482 & 1.000 & 0.402 & 0.634 \\
\hline
\end{tabular}

The Influence of Entrepreneurial Orientation, Innovation and Marketing Strategy on Competitiveness

In conducting the test for the hypothesis (resampling bootstrapping), the model used in PLS method to be tested might be used under several assumptions. Those assumptions were that data did not have to be normally distributed, the scale of measurement might be nominal, ordinal, interval or ratio, the number of

samples did not have to be big, the indicator did not have to be reflective and model did not have to be based on theory[9].

The hypothesis test is determined from the t-statistic value. The criteria for rejecting and accepting a proposed relationship can be set from the comparison between $\mathrm{t}$-count and t-table values. If the $\mathrm{t}$-count value > 
Revy Alviany et al., 2019. The Influence of Entrepreneurial Orientation, Innovation and Marketing Strategies To Competitiveness Of Food Sector Msmes In Makassar /American-Eurasian Journal of Sustainable Agriculture. 13(2): 61-67. DOI: 10.22587/aejsa.2019.13.2.7

$\mathrm{t}$-table (1.96) then the H0 is accepted. Otherwise, the $\mathrm{H} 0$ is rejected (significant regression coefficient). The next step is to conduct a significant test over the hypothesis test on the evaluation analysis of structural models based on the estimated path parameter coefficient[10]. Hypothesis testing aims to determine the significance of the influence of entrepreneurial orientation and innovation and marketing strategy on MSME's competitiveness by looking at the p-values. In addition, it can also be determined by significance testing using the t-count and the test $\mathrm{t}$-value from the bootstrapping result in PLS. Test $\mathrm{t}$-value is used to find out whether the exogenous latent variable has any real effect or the significance to the endogenous latent variable on the model in this study, as well as the magnitude of influence given[11]. Determining the significance of the hypothesis test results could be obtained from its value through the bootstrapping results made in this study.

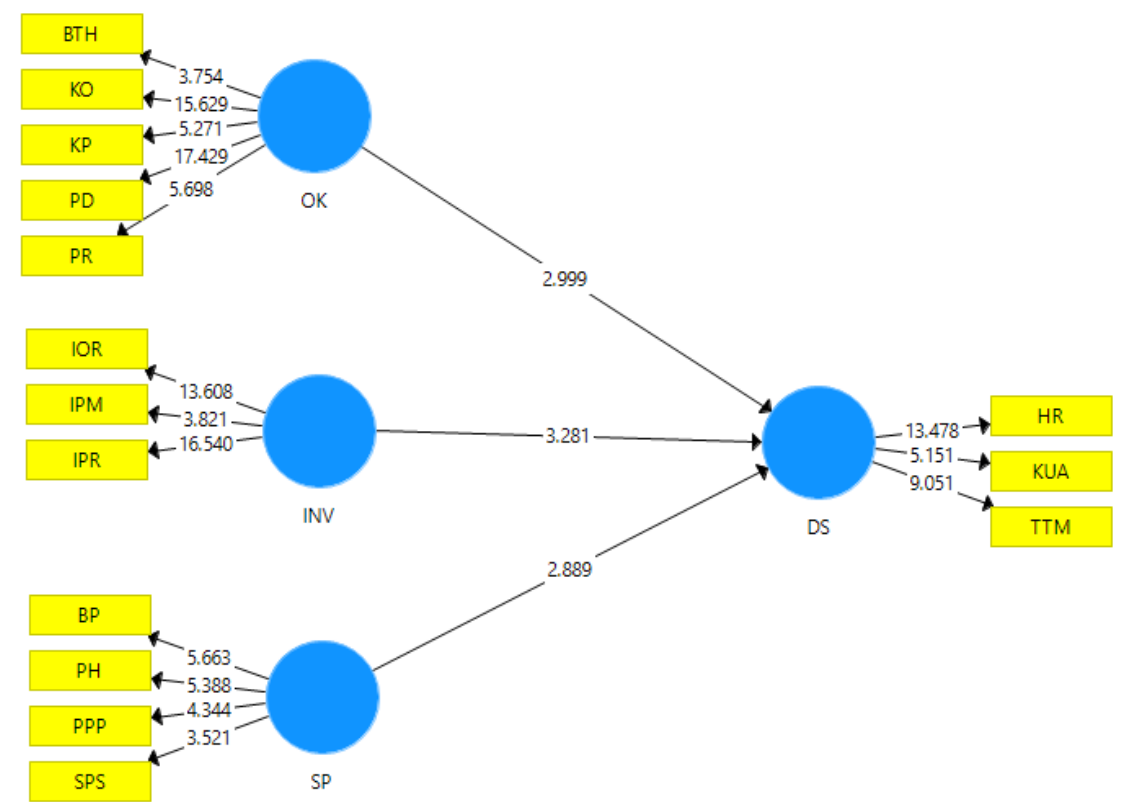

Figure 3. Test Result with Bootstrapping

Table 5. MSME Hypothesis Testing in The Food Sector

\begin{tabular}{|l|c|c|c|c|}
\hline & Coefficient & t-count & p-values & Remarks \\
\hline $\begin{array}{l}\text { Entrepreneurial orientation } \\
\longrightarrow \text { competitiveness }\end{array}$ & 0.243 & 2.999 & 0.003 & Significant \\
\hline Innovation competitiveness & 0.332 & 3.281 & 0.001 & Significant \\
\hline $\begin{array}{l}\text { Marketing strategy } \\
\longrightarrow \text { competitiveness }\end{array}$ & 0.295 & 2.889 & 0.004 & Significant \\
\hline
\end{tabular}

Note: $\mathrm{p}$-values $<0,05=$ significant; 1.96

Based on the results of hypothesis test of the path coefficient and P-values, we can conclude that entrepreneurial orientation has a direct positive and significant influence on the competitiveness with 0.05 level of significance because the p-value was below 0.05 , which was 0.003 with a coefficient of 0.243 . This result means that for each percent of entrepreneurial orientation increase, competitiveness will increase by 24.3 percent. Innovation had the $\mathrm{p}$-value of $0.001<0.05$ which means that innovation has a positive and significant effect towards competitiveness, with a coefficient value of 0.332 which means that one percent increase in innovation will improve the competitiveness by 33.2 percent. As for marketing strategy the effect on competitiveness is also positive and significant, with 0.0505 level of significance. The p-value was 0.004 which was lower than 0.05 , with a coefficient of 0.295 . It means that an increasement in marketing strategy by one percent will increase competitiveness by 29.5 percent. It can thus be concluded that hypotheses 1,2 and 3 are acceptable.

\section{CONCLUSION}

This research shows that entrepreneurial orientation, innovation and marketing strategy has a positive and significant impact on MSME's competitiveness with 0.05 level of significance because the p-value for entrepreneurial orientation were lower than 0.05 , specifically 0.003 with a coefficient of 0.243 . In innovations, p-value was $0.001<0.05$ which means that the innovation has a positive and significant effect on competitiveness with a coefficient value of 0.332 . Marketing strategy also has positive and significant effect on 
Revy Alviany et al., 2019. The Influence of Entrepreneurial Orientation, Innovation and Marketing Strategies To Competitiveness Of Food Sector Msmes In Makassar /American-Eurasian Journal of Sustainable Agriculture. 13(2): 61-67. DOI: 10.22587/aejsa.2019.13.2.7

competitiveness with 0.05 level of significance, with p-value of 0.004 that was also lower than 0.05 , and a coefficient of 0.295 which means for every one percent increase in marketing strategy will improve competitiveness by 29.5 percent.

\section{REFERENCES}

[1] Rosmadi, M. L. N. 2019. Restriksi Pengembangan UMKM di Kabupaten Bandung. Jurnal Ikraith Ekonomika. 2 (2).

[2] Khadim, E. H. Choudhury, S. R. D. 2018. Motivational Factors of Entrepreneurship in Micro and Small Enterprises: An Empirical Study in Cachar District of Assam. AENSI Publication: The Research Journal of Social Sciences, 9 (9).

[3] Ramchandra, M. V. 2019. Challenges of Micro and Small Scale Food Industries - A Study of Amednagar District, Maharashtra. AENSI Publication: The Research Journal of Social Sciences, 10 (6).

[4] Rahmat, Muhammad. 2016. Strategi Pemasaran Kripik Dangke di Kabupaten Enrekang (Tesis). Makassar: Universitas Hasanuddin.

[5] Sirajuddin, S. N., Siregar, H., Amrawaty, A. 2013. Comparative Advantage Analysis on Self Dependent and Business Partnership of Dairy Farmers. American-Eurasian Journal Of Suistainable Agriculture (AENSI), 10 (2): 165-170.

[6] Munizu, M., Pono, M., Alam, S. 2019. The Impact of Information Technology Application on Supply Chain Integration and Competitive Advantage Indonesia: Fishery Industry Context. Quality Access to Success, 20 (169), pp. 151-156.

[7] Ghozali, Imam. 2008. Stuctural Equation Modeling, Metode Alternatif dengan Partial Least Square. Semarang: Universitas Diponegoro Semarang.

[8] Widjaja dan Elsye. 2014. Pengaruh Leadership Style terhadap Learning Organization dan Quality Management untuk Meningkatkan Firm Performance. Jurnal Business Accounting Review, 2, (2).

[9] Ghozali, Imam, Hengky Latan. 2015. Konsep, Teknik, Aplikasi Menggunakan Smart PLS 3.0 Untuk Penelitian Empiris. BP Undip: Semarang.

[10] Khudhar, R. S. 2016. An Empirical Test of Information System Success Model in a University's Electronic Services. AENSI Publication: Advances in Natural and Applied Sciences, 10 (12): 54-62.

[11] Astana, I. Y., Rusdi, H. A., Wibowo, M. A. 2015. Influence of Bidding Strategy on Project Performance in Construction. AENSI Publication: Advances in Natural and Applied Sciences, 9 (5): 65-71 